\title{
Relationship between Job Equity and Performance of Employee: A Literature Review
}

\author{
Mohammed Inuwa ${ }^{1}$ \\ ${ }^{1}$ Department of Business administration, Bauchi State University Gadau, Nigeria \\ Correspondence: Department of Business administration, Bauchi State University Gadau Nigeria, Nigeria \\ Tel: +2347037099569, E-mail:inuwadem@gmail.com
}

Received: September 02, 2017

Accepted: September 08, 2017 Online Published: September 13, 2017

\begin{abstract}
Job equity plays a great role in enhancing employee's performance in the work place. Previous studies however, concentrate on other aspect that motivate an employee to perform while discussing little on how of job equity and perceived fairness as well as how its repercussion on performance of an employee. This study therefore, adopts job equity as an independent variable and employee performance as a dependent variable with the aim analysing how perceived job equity enhances employee performance. The paper reviews past studies and literatures by various researchers and come to the conclusion that job equity plays an important role in boosting employee morale and enhancing performance. Consequently, the paper recommends that managers, employers and organisation as a whole should ensure that equity and fairness is always at play in all levels of decision making, thereby making the employee safe and secured, which result in higher performance and productivity. Moreover, paper will serve as a guide towards ensuring organisational justice and it will also contribute to the field organisational behaviour and management. It also adds more details to Adams equity theory and its applicability in today's work place.
\end{abstract}

Keywords: Job Equity, Employee performance, organisational performance.

\section{Introduction}

The employees are regarded as the major business resources that facilitate the daily activities and operations of an organisation (Mudah, Rafiki \& harahap 2014). Oluwafemi (2010) asserted that organisational effectiveness and efficiency depends on how effective and efficient the employees in the organization are.Employee job performance has always been a major challenge in organizational management and adopting effective ways to motivate employees to achieve and deliver higher job performance as well as increase the organizational competitiveness is the main objective of every business organisation (Lee \& Wu 2011). Ogbulafor, (2011) suggested that the deteriorating level employee performance in Nigerian tertiary institutions is fast becoming a serious threat to survival of universities in Nigeria which needs to be addressed urgently. It is therefore believed that employee performance is instrumental to organisational growth and profitability.

Therefore, it is alleged that employee performance is contributory to organisational advancement and profitability (Poole, 2009). The employees are considered as the foremost business assets that expedite the 
Mohammed Inuwa

regular accomplishments and tasks of an establishment (Mudah, Rafiki \& harahap 2014). Similarly, Oluwafemi (2010) proclaimed that managerial usefulness and competence hinge on how effective and efficient the employees in the organization are.Understanding the level of employee level of fairness and equity will help managers of organisation in carrying out their collective responsibilities more effectively.

An employee comes along with needs, desires and capabilities which define expectations. Job equity represents the magnitude to which hopes are and match the real awards (Aziri, 2011).

In most cases today most employees feel less satisfied with their jobs which result of poor job attitude, thereby affecting the overall performance of the organisation. Those who identify justice in their organization are more likely to feel satisfied with their job and feel less to be expected to leave and feel more committed to their job (Arti, Kuldeep, \& Ekta, 2009).

The paper therefore aimed to identify the relationship between job equity and employee performance via review of literatures and past studies.

\subsection{Statement of the Problem}

Most of the times perceive injustice employees with regards to lack of clear-cut, objective criteria for promotion (Adamu, 2014). Promotions were made based on selective justice, in most cases favouritism is mostly considered when it comes to issue of promotion, training and development and other aspect of human resource management development instead of using the stated guidelines for such processes. However, it is also believed that employers are accused of been highly partial and bias when it comes issue recruitment, promotion as well as career development implying that they (management) offer employment mostly to their immediate family and friends, and also pave way for them to achieve rapid promotion and excel while ignoring other employees that are more qualified and experienced (Sawyerr 2004). This situation create a high level of inequity among other employees which demoralises them and decrease their performance drastically.

Additionally, Mowday, Porter and Steers (2013), most employees of today have a high degree of job dissatisfaction which create attitudes that are undesirable on the job and in turn degenerate their performance ability and that of their working place as well. Employees that realise perceived equity have higher chances for job satisfaction which will lead lower intention to leave as well as leading to higher level of commitment to the organisation (Arti, Kuldeep, \& Ekta, 2009).

\section{Literature Review}

\subsection{Employee Performance}

Performance of an employee on a given job or task is strategic edifice of a business as a result, elements that give rise to enriched performance must be dissected in a more critical dimension by the establishments for success, advancement and growth (Abbas \& Yaqoob, 2009).Performance and productivity of an employee is seen an issue of momentous vitality for employers, managers and the entirety of an organisations as well (Kelidbari, Dizgah, \& Yusefi, 2011).

Ahmad and Khurram (2011), are of the opinion that employee performance embodies the all-encompassing belief of the personnel in relation their conduct and aids in the direction of the achievement of the organization. Khan, Razi and Ali (2011) view employee job performance as work performance in relation both quality and quantity that is anticipated from an employee. Due to persistent competition among different business organisation, employers of labour have realise the significance of employee performance so as to strive in today's global market while realising the fact that as employee performance increases so does the firm's overall performance as well as profitability also rises (Susanty, et-al 2013).

Liao et-al, (2012), opined employee performance as workers' complete ability and productiveness in attainment 
Mohammed Inuwa

the projected value and realisation of everyday jobs in line with the prescribed procedure and timeline of the organization. In the same way Liao et-al, (2012), sees employee job performance as an index for improvements, idleness, recompenses, retributions, reviews and remuneration changes. It also gratifies the desires for employees to realize themselves.

Therefore, Performance of an employee gives room for innovativeness among employees and general firm's performance and innovativeness, in a manner that prosperous work of accomplished, inspired and zealous human resources yield ground breaking concepts for newer goods or services and also upsurge performance quality and satisfaction of the clients (Sadikoglu \& Cemal, 2010).

Furthermore, Ahmad and Shahzad (2011) argued that seeming performance of an employee expresses the entire conviction of an employee in regards to the actions and input to the attainment of the organisations goals and mission. They further mentioned that practices of compensation, evaluation of performance and practices concerning promotion of and employee are the benchmark for performance of a worker. So also, Anitha (2013) stated that performance of an employee is a gauge or pointer of monetary or other result of the employee that has undeviating relationship with organisation performance and accomplishment as well. Anitha, (2013) additionally disclose that atmosphere at which employee perform task and other schedules, relationship with bosses, co-employee relationship and that of team, compensation procedure, and engagement of an employee are determining factors for performance.

Alagaraja1 and Shuck (2015) disclose that employee performance can be measured by means of regular training and improvement. In addition, Thomas and Feldman, (2010) take on measures of employee performance as core job performance, that includes in-role performance, security performance, and inventiveness, trailed by citizenship performance, branded into equally targets-specific and wide-ranging organizational citizenship.

\subsection{Job Equity}

Adams, (1963) defines job equity as how Employees evaluate their contributions to the organization in form of input in relations to the reward they receive as output thereby estimating it based on perceived fairness or unfairness.Similarly, Banks, Patel \& Mola (2012) Define job equity as employee's perceptions of just and unjust treatment as it relates to his/her involvement in the workplace. Sees equity as employee's basis of estimation of fair and unfair treatment with regards to such employee's contribution and expectation (Aidla 2013). Moreover, Bell and Martin (2012) Define equity as how an employee judge a situation on the basis of input and output.

Base on the above given definition of job equity, it will therefore be said that equity is a psychological state that aims an employee to identify and justice as it relate to what such employee offer to an organisation and what they receive in return. It seen as a way reconciling effort and reward of an employee in the work place. Employees expect to put in their best effort towards their respective duties and schedules in order to achieve both organizational and employee goal. Equity therefore, is one of the main factors that influence employee performance in the workplace; employees evaluate their contributions to the organization in form of input in relations to the reward they receive as output thereby estimating it based on perceived fairness or unfairness (Adams, 1963).

Also, according to Kim, Edwards \& Shapiro (2014) workers always form an impression on whether they are given fair treatment in their work place or otherwise e, which impact greatly on their level of performance. This shows that an employee that perceive equity in the workplace may tend to increase the level of performance while if reverse is the case, the employee may tend to decreases performance level (Banks, Patel \& Mola 2012). Component of equity as it's relate to employee performance according to Bell and Martins (2012) include: input; output; the other on comparison basis, resultant effect of the comparison and how employee react to the 
Mohammed Inuwa

given situation.

2.3 Basis for Measuring Job Equity

According to Adams (1963), equity is classified by an employee on the basis of the following discussed below:

2.3.1 Input Basis

The first component which is input is seen as the overall contributions offered by an individual on the job or the organization in general, however Adam Stacey outlined thirteen input an individual brings in to a work place in which they estimate whether have been treated justly or not, the inputs includes; Intelligence, education training, skills, experience, seniority, age, gender, ethnic background, effort, social status, personal appearance, health, quality of work, responsibility though, over a period of time other factors were included by various scholars like loyalty, quality of work dedication and time (Griffin \& Mororhed 2011).

\subsubsection{Output Basis}

The second aspect emphasizes on the output of the individual which is seen as the result of the input or reward gained from the efforts offered by an individual which mostly is related to financial benefits or reward and status with indicates that individuals compare their income or output with other employees or their knowledge and expertise (Lventhal, Weiss, Long 1969). Recognition, supervision, uncertainty and relationship with coemployees have been included by (Aidla 2013). Adams (1963) also mention output as comprises of pay, bonus, perks, benefits, praise, reputation, responsibility.

Therefore, the study adopt of the input component like effort, skills, experience as compared against other output like pay, benefits, reputation and promotion in order to identify whether the non- academic staff perceive equity or inequity in the work place. The idea behind the measures of input against output is because Adams (1963) opined that a work that perceive balance between the two component (input and output) will perceive justice and thereby increase performance while on the other hand if the input does not equates output an employee perceives injustice and decrease performance level or some extend quit the job.

\subsubsection{Job Equity Referent Other}

It will be of paramount importance to understand that an individual worker seek justice by referring or comparing oneself to other individual worker of group of workers. It signifies that the Individual compares this input-output balance with the other employees that are of the same level of educational qualification or working experience inside or outside the organization known as 'referents' this referent other can be classified according to Robins ( 2013) as self-inside, self- outside, others inside and others outside. Below is a brief discussion of the referent other.

\subsubsection{Others Inside}

This refers to how an employee compare oneself with other co-workers that have same level of working experience and educational qualification or some extend same position but different department or unit (Robins 2013). For instance a graduate of accounting working in finance unit and another graduate in economics working in same organisation whose experience and level are the same. It is believed people mostly liken themselves with others that have similar educational qualification, expertise and work schedule (McKenna 2000).

Adams (1967) further mentioned that individuals can also compare oneself in relation to past job or in projection for the future. Therefore, the essence of using referent other of self-inside by an employee is to justify whether fairness and equity has been done within the organisation as it's relates to distribution of organisations resources. In regards to this study self- inside referent other is used considering the fact that most of the nonacademic staff of BASUG tend to compare themselves with one another in terms of pay, promotion, incentives 
and experience.

\subsubsection{Others Outside}

As the name implies in this circumstance an employee centred on a referent point of other employees working in separate organisation that is to say employees in some cases tend to weigh equity and inequity by observing how other employee in other organisation are treated in relation to pay package, promotion, training and development and inputs/outputs (Bell \& Martins 2012). An employee therefore perform better if they perceive that they have been given fair treatment in their workplace than the others outside performance increases while on the other hand if other employees outside the organisation receive better treatment than the employee making the comparison, the performance of such employee will bound to decrease due perceive injustice(Aidla 2013). However, due to poor salary scale, delay in payment of salaries, inconsistent and bias promotion practises of the Nigerian Universities, most of the non- academic staff are believed to be using the others outside referent point when seeking to determine how just or unjust they are been treated in their working place which also serves as a benchmark level of performance in the work place. It is therefore pertinent to ensure justice by management of Universities in all aspects of work in other to attain higher level of employee performance.

\subsubsection{Self- Inside}

According Robbins and judge (2013) an employee seek to identify equity by comparing oneself to experiences in a different position inside the current organisation in which the employee works. This shows that an employee compare his/her current job position with older positions held in the organisation with essence of identifying whether the benefits of the current position is much better or worthwhile compare to the older position Al- Zawahreh \& Al- Mahi (2012). This is situation if an employee perceive equity in the event, performance increases while if reverse is the case performance decreases.

\subsubsection{Self-Outside}

This situation is mostly applicable to individuals that initially work in a different place before joining their current work place. In this case an employee seeks equity through comparing one current job and previous job he/she hold outside their current work place (Robbins \& Judge 2013). Further by seeking justice through such comparison, if the employee perceives equity then performance tend to increase performance and if in equity is been perceived then such employee will have the tendency of lowering performance (Aidla 2013).

\subsection{Job Equity and Employee Performance}

According to Usmani and Jamal (2013) the concept of equity is essential for employee performance considering the fact that it has an impact on the behaviour of individual to an extent that it determines what result on higher employee performance or on the other hand decreased performance. Similarly, Pepper \& Gosling, (2015) asserted that equity has two dimensions, normative and dimension which emphasize on what should be done? And ethical dimension that is concerned with what is perceived to be just?

Al- Zawahreh \& Al- Mahi (2012) maintain that one of the motives why fair play in the workplace is vital is that employees want to sense that they have some control over their prospect with the employer which can help enhance performance. Al- Zu'bi (2010) also argue that an employee who perceive a feeling of fairness believe they are given fair compensation as a result of their input to the organisation tend to have a higher level of performance and productivity.

An imbalanced system is one in which has a lack of expectedness, so that subjective decisions are made and employee fear ill-treatment. Equity envisages that employees gauge the fairness of rewards by matching outcomes with inputs. Outcomes consist of salary, base pay, incentives, benefits, working conditions, or anything received in exchange for services. Inputs comprise education or expertise, effort expended, and other 
contributions employees believe should be rewarded (Day, 2015).

Equity theory can be used by managers to link with their juniors in order to understand that equity and fairness occur among employees. In most cases, if bosses simply talked with their juniors and describe what was desirable at a given time to get a positive level of performance, or how a given amount of monies was dispersed, their employees would be more likely to comprehend and neither reduces their productivity nor intend exit the organization (Bell \& Martin, 2012). Additionally, Mahajan and Benson, (2011) suggests that equity is positively related to job performance and negatively related to employees' intentions to quit their organization.

In a study conducted by Aidla, (2013) aimed at examining how perception of negative inequity at work influence individual behaviour at work adopted fairness, unfairness and situation as indicators for measuring inequity. However, the study concludes that employees change their outcome when they experience inequity which can result in decreased performance.

This is, however in consistent with the Adams equity theory as cited by Bell and Martin (2012) asserted that when employees sense suffering from inequality they may respond by restricting their efforts to a level they see is dependable with the outcomes they get or they may meet with their bosses to verbally discuss a healthier agreement, meaning they will try to find a equilibrium between effort and compensation. Finally, the distress mental state of inequity may make some employees to leave the job. However, equity determines the extent to which an employee performs assigned task because the current feelings or perception of an employee determine how best the task is being carried out.

\section{Discussion, Conclusion and Recommendation}

It is paramount for employers to prioritise job equity in order to ensure that employees perceive even and fair treatment in the work place. By implication employee performance can be boosted if justice and equity is at play at all levels of organisation (Bingham, 2016). An employee needs to be feeling safe and secured in the workplace if equity is at play. On the other hand inequity in an organisation can hinder employee performance and drastically demoralises employees that perceive inequity (Benowitz, 2017).

The study therefore recommends that managers, employers and organisation as a whole should ensure that equity and fairness is always at play in all levels of decision making, thereby making the employee safe and secured, which result in higher performance and productivity.

Moreover, the paper will serve as a guide towards ensuring organisational justice and it will also contribute to the field organisational behaviour and management. It also adds more details to Adams equity theory and its applicability in today's work place.

However, the study relied upon past literatures and studies. It does not apply empirical approach; therefore, it is recommended that further studies should apply empirical analysis in order to ascertain the relationship between the research variables.

\section{References}

Abbas, Q., \& Yaqoob, S. (2009). Effect of leadership development on employee performance in Pakistan. Pakistan Economic and Social Review, 269-292.

Adams, J. S. (1963). Towards an understanding of inequity. The Journal of Abnormal and Social Psychology, 67(5), 422.

Ahmad, S., \& Shahzad, K. (2011). HRM and employee performance: A case of university teachers of Azad Jammu and Kashmir (AJK) in Pakistan. African Journal of Business Management, 5(13), 5249.

Aidla, A. (2013). Perceptions of negative inequity at work and the behavior of individuals GSTF Business Review. (GBR), 2(3), 234. 
Mohammed Inuwa

Alagaraja, M., \& Shuck, B. (2015). Exploring Organizational Alignment-Employee Engagement Linkages and Impact on Individual Performance a Conceptual Model. Human Resource Development Review, 1534484314549455 .

Al-Ahmadi, H. (2009). Factors affecting performance of hospital nurses in Riyadh Region, Saudi Arabia. International Journal of Health Care Quality Assurance, 22(1), 40-54.

Anitha, J. (2014). Determinants of employee engagement and their impact on employee performance. International Journal of Productivity and Performance Management, 63(3), 308-323.

Aziri, B. (2011). Job satisfaction: A literature review. Management research and practice, 3(4), 77-86.

Benowitz, L. (2017). Justice at Work: Towards an Adaptive Workplace(Doctoral dissertation). Bingham, C. (2016). Employment Relations: Fairness and Trust in the Workplace. Sage.

Edwards, J. R., Cable, D. M., Williamson, I. O., Lambert, L. S., \& Shipp, A. J. (2006). The phenomenology of fit: linking the person and environment to the subjective experience of person-environment fit. Journal of Applied Psychology, 91(4), 802.

George, R., \& Jayan, C. (2013). Moderating Role of Organizational Culture on Job Attitude and Personal Effectiveness. Anvesha, 6(4).

Howard, A. D. (2009). An exploratory examination of positive and negative emotional attractors' impact on coaching intentional change (Doctoral dissertation, Case Western Reserve University).

Huang, W. H. D., Han, S. H., Park, U. Y., \& Seo, J. J. (2010). Managing employees' motivation, cognition, and performance in virtual workplaces: The blueprint of a game-based adaptive performance platform (GAPP). Advances in Developing Human Resources, 12(6), 700-714.

Janakiraman, R., Parish, J. T., \& Berry, L. L. (2011). The Effect of the Work and Physical Environment on Hospital Nurses' Perceptions and Attitudes: Service Quality and Commitment. The Quality Management Journal, 18(4), 36.

Kelidbari, H. R., Dizgah, M. R., \& Yusefi, A. (2011). The relationship between organization commitment and job performance of employees of Guilan Province social security organization. Interdisciplinary Journal of Contemporary Research in Business, 3(6), 555.

Khan, H. Razi, A., Ali, S.A, and Asghar A. (2011). A study on relationship between organizational job commitment, and its determinants among CSRs and managerial level employees of Pakistan (Telecommunication sector), Interdisciplinary Journal of Contemporary Research in Business, 3, (11), 269-284.

Liao, C. W., Lu, C. Y., Huang, C. K., \& Chiang, T. L. (2012). Work values, work attitude and job performance of green energy industry employees in Taiwan. African Journal of Business Management, 6(15), 5299-5318.

Mahajan, A., \& Benson, P. (2013). Organisational justice climate, social capital and firm performance. Journal of Management Development, 32(7), 721-736.

Mowday, R. T., Porter, L. W., \& Steers, R. M. (2013). Employee-organization linkages: The psychology of commitment, absenteeism, and turnover. Academic Press.

Ng, T. W., \& Feldman, D. C. (2010). Organizational tenure and job performance. Journal of Management, 36(5), $1220-1250$.

Ogbulafor C. (2011). Motivation and job performance of academic staff of state universities in Nigeria: the case of Ibrahim Badamasi Babangida University, Lapai, Niger State. International Journal of Business 
and Management, 7(14), p142.

Pepper, A., Gosling, T., \& Gore, J. (2015). Fairness, envy, guilt and greed: Building equity considerations into agency theory. Human Relations, 0018726714554663.

Poole, E. (2009). Organisational spirituality-a literature review. Journal of business ethics, 84(4), $577-588$.

Robbins, S., Judge, T. A., Millett, B., \& Boyle, M. (2013). Organisational behaviour. Pearson Higher Education AU.

Sadikoglu, E., \& Zehir, C. (2010). Investigating the effects of innovation and employee performance on the relationship between total quality management practices and firm performance: An empirical study of Turkish firms. International Journal of Production Economics, 127(1), 13-26.

Sawyerr, A. (2004). Challenges facing African universities: Selected issues. African studies review, 1-59.

Schank, R. C., \& Abelson, R. P. (2013). Scripts, plans, goals, and understanding: An inquiry into human knowledge structures. Psychology Press.

Sert, A., Elçi, M., Uslu, T., \& Şener, İ. (2014). The Effects of Organizational Justice and Ethical Climate on Perceived Work Related Stress. Procedia-Social and Behavioral Sciences, 150, 1187-1198.

Susanty, A., Miradipta, R., \& Jie, F. (2013). Analysis of the effect of attitude toward works, organizational commitment, and job satisfaction, on employee's job

Vandenabeele, W. (2009). The mediating effect of job satisfaction and organizational commitment on self-reported performance: more robust evidence of the PSM-performance relationship. International review of administrative sciences, 75(1), 11-34.

Wu, M. Y., \& Lee, Y. R. (2011). The effects of internal marketing, job satisfaction and service attitude on job performance among high-tech firm. African Journal of Business Management,5(32), 12551-12562.

\section{Copyrights}

Copyright for this article is retained by the author(s), with first publication rights granted to the journal. 